\title{
Alkyl and dialkylammonium tetrafluoroborate catalyzed cis-trans isomerization of 1,3,5-trimethyl-1,3,5-triphenylcyclotrisiloxane
}

\author{
Chiou-Ling Chang, ${ }^{\mathrm{a}}$ Man-kit Leung, ${ }^{\mathrm{a}, \mathrm{b}, *}$ and Mei-Hui Yang ${ }^{\mathrm{a}}$ \\ ${ }^{a}$ Department of Chemistry, National Taiwan University, Taipei 106, Taiwan, ROC \\ ${ }^{\mathrm{b}}$ Institute of Polymer Science and Engineering, National Taiwan University, Taipei 106, Taiwan, ROC
}

Received 27 April 2004; revised 9 July 2004; accepted 23 July 2004

Available online 27 August 2004

\begin{abstract}
Alkyl and dialkylammonium tetrafluoroborate promoted cis-trans isomerization of 1,3,5-trimethyl-1,3,5-triphenylcyclotrisiloxane (1) in DMSO- $\mathrm{d}_{6}$ were studied. The isomerization equilibrium constant $K$ are within the range of $3.74-3.30$ from 22 to $47^{\circ} \mathrm{C}$. Thermodynamic parameters of $\Delta H^{\circ}$ and $\Delta S^{\circ}$ for the isomerization were $-0.95 \mathrm{kcal} / \mathrm{mol}$ and $-0.59 \mathrm{cal} / \mathrm{mol}-\mathrm{K}$ respectively. The isomerization rate is first order in [cis-1] and second order in $\left[\mathrm{R}_{n} \mathrm{NH}_{4-n} \mathrm{BF}_{4}\right]$. Both components of $\mathrm{R}_{n} \mathrm{NH}_{4-n}^{+}$and $\mathrm{BF}_{4}^{-}$are essential for the catalytic cis-trans isomerization. The catalytic strength follows the decreasing order of ${ }^{+} \mathrm{H}_{3} \mathrm{~N}\left(\mathrm{CH}_{2}\right)_{6} \mathrm{NH}_{3}^{+}>n-\mathrm{C}_{8} \mathrm{H}_{17} \mathrm{NH}_{3}^{+}>n-\mathrm{C}_{16} \mathrm{H}_{33} \mathrm{NH}_{3}^{+}>\mathrm{Me}_{3} \mathrm{CNH}_{3}^{+}>\mathrm{PhCH}_{2} \mathrm{NH}_{3}^{+}>$ $\mathrm{Et}_{2} \mathrm{NH}_{2}^{+} \gg \mathrm{Ph}_{2} \mathrm{CHNH}_{3}^{+}, \mathrm{Et}_{3} \mathrm{NH}^{+}$. Inversion region was observed in the plot of $\ln \left(k_{\mathrm{f}} / T\right)$ versus $(1 / T)$ with the ceiling located at around $38^{\circ} \mathrm{C}$. The positive activation enthalpy of $9 \mathrm{kcal} / \mathrm{mol}$ was estimated at $22-32{ }^{\circ} \mathrm{C}$. The activation enthalpy turns to be slightly negative at $T>38{ }^{\circ} \mathrm{C}$. (C) 2004 Elsevier Ltd. All rights reserved.
\end{abstract}

\section{Introduction}

Because of their special physical properties and chemical stability, polysiloxanes have been widely used in electrical, textile, plastic, paper, automobile, with minor amounts going into food and medical products. ${ }^{1}$ Among the synthetic approaches for polysiloxanes, cationic and anionic ring opening polymerization of cyclic siloxanes attract many research teams to study. ${ }^{2}$ In particular, the ring-opening process has been considered as a key step to control the kinetics and mechanisms of the polymerization. ${ }^{3}$ Many research results suggested that chelation of metal cations by the siloxane moieties would importantly affect the polymerization process. ${ }^{4}$ Explorations of the interactions between siloxane monomers and metal cations or $\mathrm{R}_{4} \mathrm{~N}^{+}$ions have been reported. ${ }^{5}$ However, systematic studies on the interactions between cyclic siloxanes and $\mathrm{R}_{n} \mathrm{NH}_{4-n}^{+}$are rare. As our continuous interest in hydrogen bonding interactions as well as cation binding, ${ }^{6}$ we have recently investigated the possibility of using hydrogen bond donor as a catalyst to activate cyclic siloxanes for reaction. Herein we report novel conditions of alkyl or dialkylammonium tetrafluoroborate promoted cis-trans isomerization of cis1,3,5-trimethyl-1,3,5-triphenyl-cyclotrisiloxane (cis-1) (Scheme 1).

Keywords: cis-trans Isomerization; Isomerization; Polymerization.

* Corresponding author. E-mail: mkleung@ntu.edu.tw cis-trans Isomerization of cis-1 by $\mathrm{ZnCl}_{2}$ or $\mathrm{FeCl}_{3}$ as the catalyst in $\mathrm{CH}_{3} \mathrm{NO}_{2}$ at elevated temperature has been first reported by Spielvogel and Frye. ${ }^{7}$ Later on, the use of pyridinium chloride or $\mathrm{PhNH}_{3} \mathrm{Cl}$ in $\mathrm{DMF}$ as a catalyst for the isomerization has also been reported. ${ }^{8}$ However, pyridinium acetate was found to be inactive under similar conditions, implying that the counter anion indeed plays an important role on the above isomerization process. A ring opening reaction mechanism was proposed by the authors in that case.

\section{1. $\mathrm{R}_{n} \mathrm{NH}_{4-n} \mathrm{BF}_{4}$ promoted cis-trans isomerization of cis-1}

The synthesis of cis-1 has been reported in previous literature. ${ }^{9}$ The structure of $c i s-\mathbf{1}$ was further confirmed by X-ray crystallographic analysis before use. ${ }^{10,11}{ }^{1} \mathrm{H}$ NMR of cis-1 in DMSO-d 6 (Fig. 1) shows a singlet of methyl protons at $\delta 0.55 \mathrm{ppm}$, which is corresponding to the resonance of the methyl protons. cis-1 $(14.9 \mathrm{mM})$ is stable in DMSO- $\mathrm{d}_{6}$

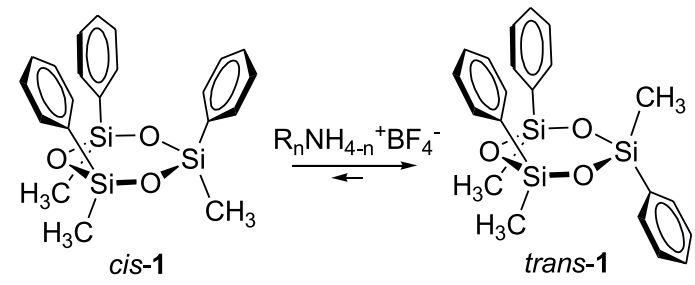

Scheme 1. 
for several days without causing any change on the spectrum. On addition of $\mathrm{NH}_{3}\left(\mathrm{CH}_{2}\right)_{6} \mathrm{NH}_{3}\left(\mathrm{BF}_{4}\right)_{2}$ or $n-\mathrm{C}_{8} \mathrm{H}_{17} \mathrm{NH}_{3} \mathrm{BF}_{4}(5 \mathrm{mM})$, two additional methyl singlets of the trans-isomer at $\delta 0.46$ and $0.41 \mathrm{ppm}$, with the integration ratio of $2: 1$, gradually appeared. These results suggested that the ammonium salt acts as a catalyst to promote the cis-trans isomerization.

To elucidate the role of the salt in this reaction, contrast experiments were run for comparison. When cis-1 (0.1 M) was treated with $n-\mathrm{C}_{8} \mathrm{H}_{17} \mathrm{NH}_{3} \mathrm{Cl}(0.1 \mathrm{M})$ at $25^{\circ} \mathrm{C}$ for three days, no reaction was observed. On the other hand, polymerization of cis-1 (0.1 M), instead of cis-trans isomerization, slowly proceeded in the presence of $\mathrm{LiBF}_{4}$ $(0.1 \mathrm{M})$. When cis-1 $(0.1 \mathrm{M})$ was treated with a mixture of $n-\mathrm{C}_{8} \mathrm{H}_{17} \mathrm{NH}_{3} \mathrm{Cl}$ and $\mathrm{LiBF}_{4}$, cis-trans isomerization occurred along with some degree of polymerization. On the contrary, $\mathrm{LiCl}(0.08 \mathrm{M})$ would lead to cis-trans isomerization but in much slower rate. Even in the presence of relatively high concentration of $\mathrm{LiCl}$, only $5 \%$ of trans-1 was observed after one day.

All these results indicate that the cis-trans isomerization requires the coexistence of both $n-\mathrm{C}_{8} \mathrm{H}_{17} \mathrm{NH}_{3}^{+}$and $\mathrm{BF}_{4}^{-}$as the catalysts. Either $n-\mathrm{C}_{8} \mathrm{H}_{17} \mathrm{NH}_{3}^{+}$or $\mathrm{BF}_{4}^{-}$alone does not effectively promote the cis-trans isomerization. The same reaction occurred in $\mathrm{CD}_{3} \mathrm{CN}$, along with some degree of polymerization. On the other hand, when $\mathrm{BF}_{4}^{-}$had been replaced by $\mathrm{ClO}_{4}^{-}$ion, a complicated reaction mixture was obtained. All this indicated that $\mathrm{BF}_{4}^{-}$should have a specific role for this isomerization.
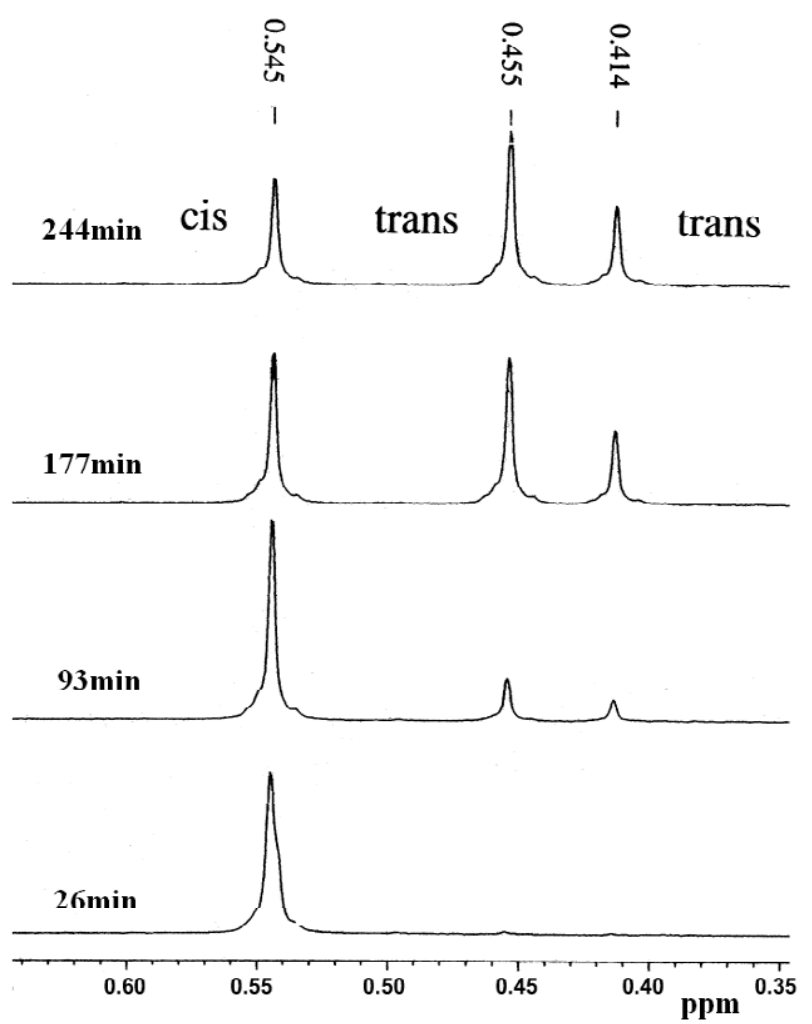

Figure 1. ${ }^{1} \mathrm{H} \mathrm{NMR}$ spectra of $\mathrm{NH}_{3}\left(\mathrm{CH}_{2}\right)_{6} \mathrm{NH}_{3}\left(\mathrm{BF}_{4}\right)_{2}(4.46 \mathrm{mM})$ catalyzed cis-trans isomerization of cis-1 $(14.9 \mathrm{mM})$ at $25.0 \pm 0.1^{\circ} \mathrm{C}$ in DMSO- $\mathrm{d}_{6}$ at: (a) $26 \mathrm{~min}$; (b) $93 \mathrm{~min}$; (c) $177 \mathrm{~min}$; (d) $244 \mathrm{~min}$.

\subsection{Kinetics and thermodynamics}

Kinetic studies revealed that the isomerization of $c i s-\mathbf{1}$ to trans-1 is first order in $\left[\right.$ cis-1].$^{8}$ The equilibrium constants for the cis-trans isomerization of $\mathbf{1}$, defined as $K=k_{\mathrm{f}}^{\text {cat }} /$ $k_{b}^{c a t}=[\text { trans }]_{\mathrm{eq}} /[c i s]_{\mathrm{eq}}$, were evaluated at various temperatures in

$$
\operatorname{cis}-\mathbf{1} \underset{k_{\mathrm{b}}^{\text {cat }}}{\stackrel{k_{\mathrm{f}}^{\text {cat }}}{\rightleftharpoons}} \operatorname{trans}-\mathbf{1}
$$

DMSO- $d_{6}$ and are listed in Table 1. The equilibrium constants $K$ are within the range of 3.74-3.30 from 22$47^{\circ} \mathrm{C}$. Thermodynamic parameters of $\Delta H^{\circ}$ and $\Delta S^{\circ}$ were determined from a linear plot of $\ln K$ versus $1 / T$ and were found to be $-0.95 \mathrm{kcal} / \mathrm{mol}$ and $-0.59 \mathrm{cal} / \mathrm{mol}-\mathrm{K}$ respectively. Although the sign of $\Delta H^{\circ}$ is consistent with the prediction based on the ring strain energy $\left(E_{\mathrm{s}}\right)$ measurements, in which cis-cyclotrisiloxane isomer has slightly higher ring strain than the trans one, ${ }^{12}$ the $\Delta H^{\circ}$ of $-0.95 \mathrm{kcal} / \mathrm{mol}$ is relatively small in comparison to the reported $\Delta E_{\mathrm{s}}$ of $-2.1 \mathrm{kcal} / \mathrm{mol}$. The negative entropy of $-0.59 \mathrm{cal} / \mathrm{mol}-\mathrm{K}$ may be attributed to the siloxane-DMSO interactions that restricted the degree of freedom of the solvent molecules. Noteworthy to mention are the facts that the literature values of $[$ trans $] /[\mathrm{cis}]$ were found to be nearly equal to 3 either in methylcyclohexane ${ }^{13}$ or in nitromethane, ${ }^{7}$ indicating that the solvent effects on the equilibrium are small.

The mathematical expression for the first order kinetics described above is shown as the following equation.

$\ln \left(\frac{[\operatorname{cis}-\mathbf{1}]_{t}}{[\operatorname{cis} \mathbf{- 1}]_{0}}-\frac{1}{K+1}\right)=-k_{\mathrm{f}}^{\mathrm{cat}}\left(1+\frac{1}{K}\right) t+\ln \left(\frac{K}{K+1}\right)$

In the kinetic expression, $[\text { cis-1 }]_{\mathrm{o}}$ is the initial concentration of $[c i s-\mathbf{1}], k_{\mathrm{f}}^{\text {cat }}$ is the rate constant for the forward reaction, $t$ is the reaction time elapsed, $[\mathrm{cis}-\mathbf{1}]_{t}$ is the concentration of $[$ cis-1 $]$ at time t. ${ }^{14}$ Linear regression of $\ln \left\{[\text { cis-1 }]_{t} /[\text { cis-1 }]_{0}-\right.$ $1 /(K+1)\}$ versus $t$ gave a slope of $-k_{\mathrm{f}}^{\text {cat }}(1+1 / K)$. Since the equilibrium constant $K$ had been measured in the previous equilibrium experiments, the values of $k_{\mathrm{f}}^{\text {cat }}$ could then be calculated. In most of the kinetic runs, the data were collected up to $80 \%$ conversion and the linearity of the plots are usually good with the correlation coefficient larger than 0.99 . Since the value of $k_{\mathrm{f}}^{\text {cat }}$ obtained above should be a function of concentration of the catalyst, we tentatively proposed an empirical formula of $k_{\mathrm{f}}^{\mathrm{cat}}=k_{\mathrm{f}}\left[\mathrm{R}_{n} \mathrm{NH}_{4-{ }_{n}} \mathrm{BF}_{4}\right]_{\mathrm{o}}^{\mathrm{P}}$, in which $\left[\mathrm{R}_{n} \mathrm{NH}_{4-n} \mathrm{BF}_{4}\right]_{\mathrm{o}}$ is the concentration of the alkylammonium tetrafluoroborate used in the reaction, and the original first order kinetic equation could be reexpressed as follows.

Table 1. Equilibrium constants $K=[\text { trans }]_{\mathrm{eq}} /[\mathrm{cis}]_{\mathrm{eq}}$ and the Gibbs free energy change for the cis-trans isomerization of cis-1 at various temperatures

\begin{tabular}{lcc}
\hline Temperature $\left({ }^{\circ} \mathrm{C}\right)$ & $K$ & $\Delta G^{\circ}(\mathrm{kcal} / \mathrm{mol})$ \\
\hline $22.0 \pm 0.2$ & 3.74 & -0.774 \\
$26.0 \pm 0.2$ & 3.65 & -0.770 \\
$37.0 \pm 0.2$ & 3.44 & -0.761 \\
$47.0 \pm 0.2$ & 3.30 & -0.759 \\
\hline
\end{tabular}


Table 2. Determination of the reaction order $\mathrm{P}$ from a plot of $\ln \left[k_{\mathrm{f}}^{\text {cat }}\right]$ versus $\ln \left[\mathrm{R}_{n} \mathrm{NH}_{4-n} \mathrm{BF}_{4}\right]$

\begin{tabular}{lc}
\hline $\mathrm{R}_{n} \mathrm{NH}_{4-n}^{+}$ & Reaction order \\
\hline$n-\mathrm{C}_{8} \mathrm{H}_{17} \mathrm{NH}_{3}^{+} \mathrm{a}$ & 2.53 \\
$\mathrm{PhCH}_{2} \mathrm{NH}_{3}^{+}$a & 2.07 \\
$\left.{ }^{+} \mathrm{H}_{3} \mathrm{~N}_{(} \mathrm{CH}_{2}\right)_{6} \mathrm{NH}_{3}^{+} \mathrm{a}$ & 2.05 \\
$n-\mathrm{C}_{8} \mathrm{H}_{17} \mathrm{NH}_{3}^{+}$ & 2.14 \\
\hline
\end{tabular}

${ }^{\text {a }}$ At $T=25.0 \pm 0.1^{\circ} \mathrm{C}$.

b At $T=47.0 \pm 0.1^{\circ} \mathrm{C}$.

$-\frac{\mathrm{d}[c i s-\mathbf{1}]}{\mathrm{d} t}=k_{\mathrm{f}}^{\mathrm{cat}}[c i s-\mathbf{1}]=k_{\mathrm{f}}\left[\mathrm{R}_{n} \mathrm{NH}_{4-n} \mathrm{BF}_{4}\right]_{o}^{p}[c i s-\mathbf{1}]$.

Table 2 summarized the reaction orders $p$ obtained from the slope of the plots of $\ln \left(k_{\mathrm{f}}^{\text {cat }}\right)$ versus $\ln \left[\mathrm{R}_{n} \mathrm{NH}_{4-n} \mathrm{BF}_{4}\right]_{\mathrm{o}}$. For the ammonium salts we studied, the $p$ values at $25^{\circ} \mathrm{C}$ were found to be or slightly larger than 2 with an average of $2.2 \pm$ 0.2 . Fractional order in pyridinum chloride catalyzed cistrans isomerization has been previously reported in literature. $^{8}$

Although the reaction order obtained above is not exactly equal to 2, particularly in the case of $\mathrm{C}_{8} \mathrm{H}_{17} \mathrm{NH}_{3} \mathrm{BF}_{4}$ where the $p$ value was found to be 2.53 in the regression, their second order plots of $k_{\mathrm{f}}^{\text {cat }}$ versus $\left[\mathrm{R}_{n} \mathrm{NH}_{4-n} \mathrm{BF}_{4}\right]^{2}$ are very linear with the correlation coefficient larger than 0.99 . Therefore, we tentatively assigned the reaction order $p$ as 2 . To compare the catalytic strength of different alkylammonium tetrafluoroborates, their $k_{\mathrm{f}}$ values (Table 3 ) were evaluated at $25 \pm 0.1{ }^{\circ} \mathrm{C}$ with $\left[\mathrm{R}_{n} \mathrm{NH}_{4-n} \mathrm{BF}_{4}\right]_{\mathrm{o}}$ around $6 \mathrm{mM}$. Their reactivity follows the decreasing order of ${ }^{+} \mathrm{H}_{3} \mathrm{~N}\left(\mathrm{CH}_{2}\right)_{6} \mathrm{NH}_{3}^{+}>n-\mathrm{C}_{8} \mathrm{H}_{17} \mathrm{NH}_{3}^{+}>n-\mathrm{C}_{16} \mathrm{H}_{33} \mathrm{NH}_{3}^{+}>\mathrm{Me}_{3}$ $\mathrm{CNH}_{3}^{+}>\mathrm{PhCH}_{2} \mathrm{NH}_{3}^{+}>\mathrm{Et}_{2} \mathrm{NH}_{2}^{+} \gg \mathrm{Ph}_{2} \mathrm{CHNH}_{3}^{+}, \mathrm{Et}_{3} \mathrm{NH}^{+}$. Less hindered primary alkylammonium cations such as $n-\mathrm{C}_{8} \mathrm{H}_{17} \mathrm{NH}_{3}^{+}, n-\mathrm{C}_{16} \mathrm{H}_{33} \mathrm{NH}_{3}^{+}$and ${ }^{+} \mathrm{H}_{3} \mathrm{~N}\left(\mathrm{CH}_{2}\right)_{6} \mathrm{NH}_{3}^{+}$show highest reactivity for the cis-trans isomerization. For ammonium cations bearing larger substituent such as $\mathrm{Me}_{3} \mathrm{CNH}_{3}^{+}$and $\mathrm{PhCH}_{2} \mathrm{NH}_{3}^{+}$, or secondary alkylammonium cations such as $\mathrm{Et}_{2} \mathrm{NH}_{2}^{+}$, their $k_{\mathrm{f}}$ values drop significantly by almost one order of magnitude. In addition, very sterically hindered $\mathrm{Ph}_{2} \mathrm{CHNH}_{3}^{+}$and $\mathrm{Et}_{3} \mathrm{NH}^{+}$or tetraalkylammonium tetrafluoroborates such as $\mathrm{Et}_{4} \mathrm{NBF}_{4}$ basically show no catalytic reactivity in our study.

The cis-trans isomerization also proceeds in $\mathrm{CD}_{3} \mathrm{CN}$ but in much slower rate. The isomerization kinetics was found to be second order in $\left[\mathrm{C}_{8} \mathrm{H}_{17} \mathrm{NH}_{3} \mathrm{BF}_{4}\right]$ with the $k_{\mathrm{f}}$ value of $1.6 \mathrm{~min}^{-1} \mathrm{M}^{-2}$ under the condition of $\left[\mathrm{R}_{n} \mathrm{NH}_{4-n} \mathrm{BF}_{4}\right]_{\mathrm{o}}=$ $6 \mathrm{mM}$, which is 2 order of magnitude slower than that in DMSO- $d_{6}$.

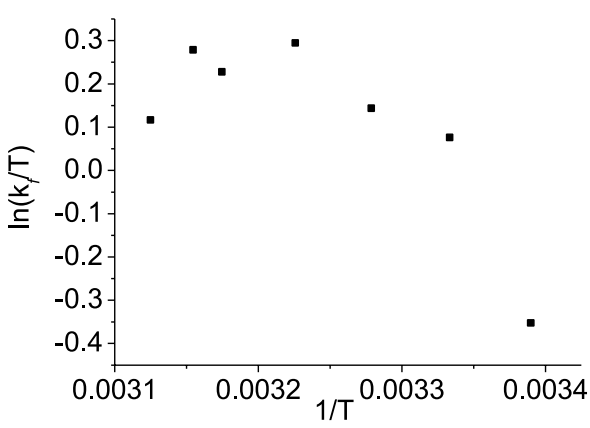

Figure 2. A plot of $\ln \left(k_{\mathrm{f}} / T\right)$ versus $1 / T$.

To further understand the reaction mechanism of the cistrans isomerization, temperature variation experiments were carried out, in which $n-\mathrm{C}_{8} \mathrm{H}_{17} \mathrm{NH}_{3} \mathrm{BF}_{4}$ was used as the catalyst. The order $p$ in $\left[n-\mathrm{C}_{8} \mathrm{H}_{17} \mathrm{NH}_{3} \mathrm{BF}_{4}\right]$ in the kinetic expression changed slightly from 2.53 to 2.14 when the temperature was varied from $25{ }^{\circ} \mathrm{C}$ to $47^{\circ} \mathrm{C}$. Although variation of the reaction order with temperature could be attributed to the intrinsic behavior of this reaction, experimental errors arising from independent kinetic runs as well as linear regression may also lead to similar extents of uncertainty. Since the variation of the reaction order is relatively small, we keep therefore our assumption that the order of $p$ is equal to 2 for the following evaluation. The $k_{\mathrm{f}}$ for $n-\mathrm{C}_{8} \mathrm{H}_{17} \mathrm{NH}_{3} \mathrm{BF}_{4}$ were measured at seven different temperatures and the data are shown in Figure 2. Inversion region was observed in the plot of $\ln \left(k_{\mathrm{f}} / T\right)$ versus $(1 / T)$ with the ceiling at around $38{ }^{\circ} \mathrm{C}$. The positive activation enthalpy of $9 \mathrm{kcal} / \mathrm{mol}$ was estimated at the temperature region of $22-32{ }^{\circ} \mathrm{C}$. ${ }^{8}$ The activation enthalpy turns to slightly negative at the temperature region higher than $38^{\circ} \mathrm{C}$. This observation suggested a complex reaction mechanism for the catalytic isomerization. Nevertheless, the existence of the inversion region could possibly be rationalized by an associative mechanism with a pre-complexation step followed by a rate determining cis-trans isomerization step. When the temperature increases, the rate determining cis-trans isomerization step is accelerated while the precomplexation step is retarded. When the temperature is high enough, the entropically less favored pre-complex formation may become unfavorable that the pre-equilibrium kinetics is no longer valid. This will lead to a non-linear plot of $\ln \left(k_{\mathrm{f}} / T\right)$ versus $(1 / T)$ in the temperature variation experiments.

Although the explanation for the slightly negative activation enthalpy at the high temperature region may not be immediately obvious, the associative mechanistic argument of pre-complex formation is consistent with at least two

Table 3. Catalytic rate constants $k_{\mathrm{f}}$ for various alkylammonium tetrafluoroborates

\begin{tabular}{lccc}
\hline $\mathrm{R}_{n} \mathrm{NH}_{4-n}^{+}$ & {$\left[\mathrm{R}_{n} \mathrm{NH}_{4-n} \mathrm{BF}_{4}\right]\left(10^{-3} \mathrm{M}\right)$} & $k_{\mathrm{f}}^{\text {cat }}\left(\mathrm{min}^{-1}\right)$ & $k_{\mathrm{f}}\left[\mathrm{k}_{\mathrm{rel}}\right]\left(\mathrm{min}^{-1} \mathrm{M}^{-2}\right)$ \\
\hline$n-\mathrm{C}_{8} \mathrm{H}_{17} \mathrm{NH}_{3}^{+}(\mathbf{2})$ & 5.37 & $1.04 \times 10^{-2}$ & $360[1]$ \\
$\left.{ }^{+} \mathrm{H}_{3} \mathrm{~N}^{-2} \mathrm{CH}_{2}\right)_{6} \mathrm{NH}_{3}^{+}(\mathbf{3})$ & 5.78 & $1.53 \times 10^{-2}$ & $459[1.3]$ \\
$n-\mathrm{C}_{16} \mathrm{H}_{33} \mathrm{NH}_{3}^{+}(\mathbf{4})$ & 5.99 & $5.07 \times 10^{-3}$ & $141[0.39]$ \\
$\mathrm{Me}_{3} \mathrm{CNH}_{3}^{+}(\mathbf{5})$ & 6.37 & $1.23 \times 10^{-3}$ & $30[0.103]$ \\
$\mathrm{PhCH}_{2} \mathrm{NH}_{3}^{+}(\mathbf{6})$ & 6.18 & $1.12 \times 10^{-3}$ & $29[0.078]$ \\
$\mathrm{Et}_{2} \mathrm{NH}_{2}^{+}(\mathbf{7})$ & 5.86 & $6.00 \times 10^{-4}$ & $18[0.046]$ \\
$\mathrm{Et}_{3} \mathrm{NH}^{+}(\mathbf{8})$ & 5.83 & Very slow & - \\
$\mathrm{Ph}_{2} \mathrm{CHNH}_{3}^{+}(\mathbf{9})$ & 7.73 & Very slow & - \\
$\mathrm{PheNH}_{3}^{+}(\mathbf{1 0})$ & 5.89 & Very slow & - \\
\hline
\end{tabular}


features: (1) Sterically hindered alkylammonium salts that do not favor the pre-complex formation usually show low catalytic activity for the reaction; (2) Heat releasing but entropically unfavored pre-complex formation may be a key reason for the slightly negative activation enthalpy at higher temperature region. ${ }^{15}$

Since hydrogen bonding between organic acids and cyclotrisiloxane has long been proposed in literature, ${ }^{16}$ it is reasonable to suggest that hydrogen bond complexation may involve in this cis-trans isomerization. However, the chemical instability of cis-1 in the ammonium salt solution hampered the direct study of the hydrogen bond intermediate. To elucidate the possibility of hydrogen bond complex formation, we selected a system of hexamethylcyclotrisiloxane $\left(\mathrm{D}_{3}\right) / \mathrm{PhCH}_{2} \mathrm{NH}_{3} \mathrm{BF}_{4}$ in $\mathrm{CD}_{3} \mathrm{CN}$ as the model to investigate. $\mathrm{D}_{3}$ is chemically stable and would not lead to other products in the presence of $\mathrm{RNH}_{3} \mathrm{BF}_{4}$. In addition, $\mathrm{PhCH}_{2} \mathrm{NH}_{3} \mathrm{BF}_{4}$ is the least reactive primary alkylammonium salt in the list we have studied. Furthermore, the reactivity of the isomerization in $\mathrm{CD}_{3} \mathrm{CN}$ is lower according to previous results.

In $\mathrm{CD}_{3} \mathrm{CN}$, up-field shift of the $\mathrm{N}-\mathrm{H}$ signal of $\mathrm{PhCH}_{2} \mathrm{NH}_{3} \mathrm{BF}_{4}$ $(0.09 \mathrm{M})$, from $6.5 \mathrm{ppm}$ approaching to $5.9 \mathrm{ppm}$, was observed when the added amount of $\mathrm{D}_{3}$ gradually increased. The data is summarized in Table 4. These results suggested that hydrogen bond complexation of $\mathrm{RNH}_{3}^{+} \cdots \mathrm{D}_{3}$ occurs in this case. The unusual direction of upfield-shift of the $\mathrm{N}-\mathrm{H}$ signal may be due to the change of the coordination shell throughout complexation. Hydrogen bond accepting properties of nitriles have recently been studied by combining crystallographic data as well as theoretical calculation. ${ }^{17}$ Before complexation, the $\mathrm{RNH}_{3}^{+}$should be coordinated with either $\mathrm{CD}_{3} \mathrm{CN}$ or $\mathrm{BF}_{4}^{-}$. Since both of them will have hydrogen bonding with $\mathrm{RNH}_{3}^{+}$, the $\mathrm{N}-\mathrm{H}$ signal is relatively down-field shift. On complexation, the coordination shell of $\mathrm{RNH}_{3}^{+}$will be partially occupied by a $\mathrm{D}_{3}$ molecule, leading to an up-field shift of the $\mathrm{N}-\mathrm{H}$ signal. Similar results were obtained for $n-\mathrm{C}_{16} \mathrm{H}_{33} \mathrm{NH}_{3} \mathrm{BF}_{4}$. Since DMSO and acetonitrile are hydrogen bond acceptors with similar polarity, ${ }^{18}$ we expected that formation of $\mathrm{RNH}_{3}^{+} \cdots$ cis-1 as a reactive intermediate in DMSO is possible.

The role of $\mathrm{BF}_{4}^{-}$is also an interesting target to study. Perfluorinated complex anions such as $\mathrm{BF}_{4}^{-}$, or $\mathrm{PF}_{6}^{-}$have been regarded as non-nucleophilic and inert of innocent anions. ${ }^{19}$ If $\mathrm{BF}_{4}^{-}$involves in the catalytic process, one may expect that changing the concentration of $\mathrm{BF}_{4}^{-}$would lead to significant effect on the reaction rate. Therefore, we have attempted using $\mathrm{Et}_{4} \mathrm{NBF}_{4}$ as independent $\mathrm{BF}_{4}^{-}$source to control the $\mathrm{BF}_{4}^{-}$concentration. However, addition of

Table 4. $\mathrm{N}-\mathrm{H}$ Chemical shifts of $\mathrm{PhCH}_{2} \mathrm{NH}_{3} \mathrm{BF}_{4}$ in the presence of various amounts of $\mathrm{D}_{3}$

\begin{tabular}{lc}
\hline$\left[\mathrm{D}_{3}\right] /\left[\mathrm{PhCH}_{2} \mathrm{NH}_{3} \mathrm{BF}_{4}\right]$ & $\delta(\mathrm{N}-\mathrm{H})(\mathrm{ppm})$ \\
\hline 0 & 6.51 \\
0.21 & 6.39 \\
1.85 & 6.18 \\
3.15 & 6.05 \\
4.64 & 5.98 \\
6.33 & 5.93 \\
\hline
\end{tabular}

At $T=25.0 \pm 0.1{ }^{\circ} \mathrm{C}$ with $\left[\mathrm{PhCH}_{2} \mathrm{NH}_{3} \mathrm{BF}_{4}\right]=0.09 \mathrm{M}$.
$\mathrm{Et}_{4} \mathrm{NBF}_{4}$ to the solution of $\mathrm{RNH}_{3} \mathrm{BF}_{4}$ does not significantly alter the reaction rate of isomerization. We tentatively attributed this result to the ion pair association of $\mathrm{Et}_{4} \mathrm{NBF}_{4}{ }^{20}{ }^{20}$ In particular, in the absence of hydrogen bond interactions, solvation of the bulky $\mathrm{Et}_{4} \mathrm{~N}^{+}$with DMSO is expected to be poor. Furthermore, we have observed the reactivity-suppression effects of $\mathrm{Et}_{4} \mathrm{NCl}$ on $\mathrm{RNH}_{3} \mathrm{BF}_{4}$. In an independent experiment, we discovered that the catalytic strength of $n-\mathrm{C}_{16} \mathrm{H}_{33} \mathrm{NH}_{3} \mathrm{BF}_{4}(5.9 \mathrm{mM})$ was reduced by $60 \%$ in the presence of $\mathrm{Et}_{4} \mathrm{NCl}(14 \mathrm{mM})$. This result is consistent with the above assumption of ion-pair formation. Addition of $\mathrm{Et}_{4} \mathrm{~N}^{+}$salt to a solution of $\mathrm{RNH}_{3} \mathrm{BF}_{4}$ would lead to $\mathrm{Et}_{4} \mathrm{NBF}_{4}$ ion-pair formation, reducing the effective concentration of free $\mathrm{BF}_{4}^{-}$ions, and hence suppressing the catalytic reactivity of the $\mathrm{RNH}_{3} \mathrm{BF}_{4}$ solution.

Since ion pair association in organic solvents is complicated, ${ }^{21}$ detailed study of the reaction order would be relatively difficult. Although it is known that $\mathrm{BF}_{4}^{-}$would dissociate into $\mathrm{BF}_{3}+\mathrm{F}^{-}$at high temperature, ${ }^{19,22}$ it is unlikely to undergo this process in our case because the reactions were carried out only at room temperature or slightly above room temperature. Furthermore, the present of $\mathrm{F}^{-}$would lead to polymerization ${ }^{23}$ that has not been observed during cis-trans isomerization. On the other hand, $\mathrm{BF}_{4}^{-}$has been proposed to act as a nucleophile to coordinate directly and react with group IV compound. ${ }^{24}$ Although mechanistically we do not have evidence for the complexation of cis-1 with $\mathrm{BF}_{4}^{-}$, our results again indicated that $\mathrm{BF}_{4}^{-}$ is not truly innocent.

Although the details of the mechanism are not completely understood, pre-complexation involving $\mathrm{R}_{n} \mathrm{NH}_{4-n}^{+}, \mathrm{BF}_{4}^{-}$ and cis-1 before isomerization to the trans isomer is plausible. We therefore proposed a mechanistic schematic diagram shown in Scheme 2. We believed that a push-pull mechanism involving hydrogen bond interaction between

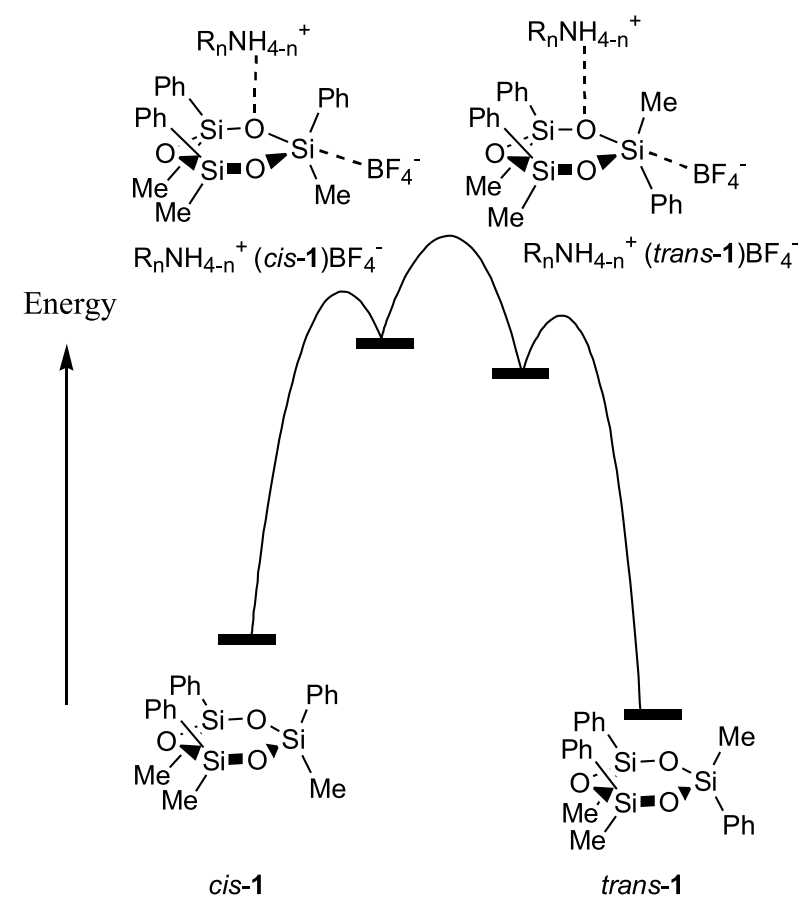

Scheme 2 . 


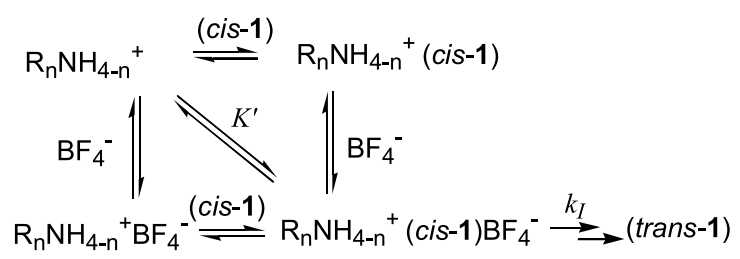

Scheme 3.

$\mathrm{R}_{n} \mathrm{NH}_{4-n}^{+}$and the oxygen atom of the $\mathrm{Si}-\mathrm{O}-\mathrm{Si}$ units, and probably coordination of $\mathrm{BF}_{4}^{-}$with the silicon atoms are operating for the cis-trans isomerization.

On the basis of this assumption, a putative mechanism is proposed as shown in Scheme 3. We have already discussed the possibility of $\mathrm{R}_{n} \mathrm{NH}_{4-n}^{+}($cis-1) complex formation. Since there is a positive charge on $\mathrm{R}_{n} \mathrm{NH}_{4-n}^{+}($cis-1), further formation of a reactive ion pair intermediate of $\mathrm{R}_{n} \mathrm{NH}_{4-n}^{+}\left(\right.$cis-1)BF ${ }_{4}^{-}$is not impossible. On the other hand, the possibility of the formation of $\mathrm{R}_{n} \mathrm{NH}_{4-}^{+}\left(\right.$cis-1) $\mathrm{BF}_{4}^{-}$ through the ion pair of $\mathrm{R}_{n} \mathrm{NH}_{4-}^{+}{ }_{n} \mathrm{BF}_{4}^{-}$could not be eliminated. Once the $\mathrm{R}_{n} \mathrm{NH}_{4-n}^{+}($cis $-\mathbf{1}) \mathrm{BF}_{4}^{-}$is formed, pseudorotational isomerization of $\mathrm{R}_{n} \mathrm{NH}_{4-n}^{+}\left(\right.$cis-1) $\mathrm{BF}_{4}$ at the pentacoordinated silicon atom may occur to give $\mathrm{R}_{n} \mathrm{NH}_{4-n}^{+}\left(\right.$trans-1) $\mathrm{BF}_{4}^{-}$, followed by dissociation of the ion-pair complex would give trans-1 as the product. This type of pseudorotational mechanism is known as the Berry pseudorotation and turnstile twists that have been studied and reviewed in literature. ${ }^{25}$

A rate equation could then be derived on the basis of the reaction scheme, in which $K^{\prime}=\left[\mathrm{R}_{n} \mathrm{NH}_{4-n}^{+}\left(\right.\right.$cis-1) $\left.\mathrm{BF}_{4}^{-}\right] /$ $\left[\mathrm{R}_{n} \mathrm{NH}_{4-n}^{+}\right]\left[\mathrm{BF}_{4}\right][$ cis-1] is the overall equilibrium constant for $\mathrm{R}_{n} \mathrm{NH}_{4-n}^{+}\left(\right.$cis-1) $\mathrm{BF}_{4}^{-}$formation, and $k_{I}$ is the isomerization rate constant from $\mathrm{R}_{n} \mathrm{NH}_{4-n}^{+}\left(\right.$cis-1) $\mathrm{BF}_{4}^{-}$to the trans isomer.

$$
\begin{aligned}
-\frac{\mathrm{d}[c i s-\mathbf{1}]}{\mathrm{d} t} & =k_{\mathrm{I}}\left[\mathrm{R}_{n} \mathrm{NH}_{4-n}^{+}(c i s-\mathbf{1}) \mathrm{BF}_{4}^{-}\right] \\
& =k_{\mathrm{I}} K^{\prime}\left[\mathrm{R}_{n} \mathrm{NH}_{4-n}^{+}\right]\left[\mathrm{BF}_{4}^{-}\right][\text {cis }-\mathbf{1}]
\end{aligned}
$$

However, this equation does not straightly explain for the observeation of the second reaction order in $\left[\mathrm{R}_{n} \mathrm{NH}_{4-n} \mathrm{BF}_{4}\right]_{\mathrm{o}}$, unless we assumed that dissociation of $\mathrm{R}_{n} \mathrm{NH}_{4-}{ }_{n} \mathrm{BF}_{4}$ in DMSO is extensive. This may be plausible due to strong hydrogen bond interactions between $\mathrm{R}_{n} \mathrm{NH}_{4-n} \mathrm{BF}_{4}$ If the assumption is valid, each equivalent of $\mathrm{R}_{n} \mathrm{NH}_{4-n} \mathrm{BF}_{4}$ would dissociate to give respectively one equivalent of $\mathrm{R}_{n} \mathrm{NH}_{4-n}^{+}$and $\mathrm{BF}_{4}^{-}$, and therefore $\left[\mathrm{R}_{n} \mathrm{NH}_{4-n}^{+}\right]$and $\left[\mathrm{BF}_{4}^{-}\right]$are both equal to $\left[\mathrm{R}_{n} \mathrm{NH}_{4-n} \mathrm{BF}_{4}\right]_{\mathrm{o}}$. Substitution these into the above equation would give the following equation,

$-\frac{\mathrm{d}[c i s-\mathbf{1}]}{\mathrm{d} t}=k_{\mathrm{f}}\left[\mathrm{R}_{n} \mathrm{NH}_{4-n} \mathrm{BF}_{4}\right]_{0}^{2}[c i s-\mathbf{1}]$

where $k_{I} K$ could be combined and denoted as the $k_{\mathrm{f}}$. The second order kinetics in $\left[\mathrm{R}_{n} \mathrm{NH}_{4-n} \mathrm{BF}_{4}\right]_{\mathrm{o}}$ could then be explained.

\section{Experimental}

All reactions were performed under nitrogen. Acetonitrile was dried over $\mathrm{CaH}_{2} .{ }^{1} \mathrm{H}$ and ${ }^{13} \mathrm{C}$ NMR spectra were recorded on a Varian Unity plus $(400 \mathrm{MHz})$. All $400 \mathrm{MHz}$ ${ }^{1} \mathrm{H}$ NMR spectra were recorded in $\mathrm{CDCl}_{3}$ deuterated acetonitrile $\left(\mathrm{CD}_{3} \mathrm{CN}\right)$ and deuterated dimethylsulfoxide $\left(\mathrm{DMSO}-\mathrm{d}_{6}\right)$ and are reported in ppm as $\delta$. The kinetic experiments were carried out in DMSO- $\mathrm{d}_{6}$. The ${ }^{1} \mathrm{H}$ NMR assignments for cis-1 and trans-1 were previously reported in literature. ${ }^{7,8,13}$ Infrared spectra were obtained with $\mathrm{KBr}$ using Nicolet MAGNA-IR 550 spectrometer series type FTIR and are reported in $\nu$ as $\mathrm{cm}^{-1}$. Elemental analysis was performed by Heraeus CHN-O Rapid.

\subsection{General procedure for the kinetic measurements}

The kinetic measurements were performed by using ${ }^{1} \mathrm{H}$ NMR spectroscopy (Varian Unity plus (400 MHz)) with temperature control. Solution of cis-1 and solution of the ammonium salt with known concentrations in DMSO- $\mathrm{d}_{6}$ were prepared before measurement. Both solutions were pre-warmed to the desired temperature, mixed, and subjected to the NMR spectrometer for data collection. The concentrations of $c i s-\mathbf{1}$ after mixing were set within the range of 8.48 to $25.5 \mathrm{mM}$. The concentrations of the ammonium salts were set within the range of 1.19 to $12.6 \mathrm{mM}$. The progress of the isomerization of cis-1 to trans $\mathbf{1}$ was monitored by taking the NMR spectrum for every 15 to $30 \mathrm{~min} .{ }^{1} \mathrm{H}$ NMR of $\mathrm{cis}-\mathbf{1}$ in DMSO-d $\mathrm{d}_{6}$ shows a singlet of methyl protons at $\delta 0.55 \mathrm{ppm}$, which is corresponding to the resonance of the methyl protons. On addition of the ammonium salt solution, two additional methyl singlets of the trans-isomer at $\delta 0.46$ and $0.41 \mathrm{ppm}$ gradually appeared. The ratio of $[$ trans $-\mathbf{1}] /[$ cis-1 $]$ at a time could be determined on the basis of the methyl proton integrations. For the temperature variation experiments, the temperature range of $25-47^{\circ} \mathrm{C}$ was used. The rate constant was determined according to the equation

$\ln \left(\frac{[\text { cis-1 }]_{t}}{[\operatorname{cis}-\mathbf{1}]_{0}}-\frac{1}{K+1}\right)=-k_{\mathrm{f}}^{\text {cat }}\left(1+\frac{1}{K}\right) t+\ln \left(\frac{K}{K+1}\right)$

By using linear least square fitting of $\ln \left([\mathrm{cis}-\mathbf{1}]_{t} /[\mathrm{cis}-\mathbf{1}]_{\mathrm{o}}-\right.$ $(1 / K+1))$ versus $t$, a slope of $-k_{\mathrm{f}}^{\text {cat }}(1+1 / K)$ could be obtained. The value of $k_{\mathrm{f}}^{\text {cat }}$ could then be calculated.

\subsection{General procedure for the preparation of alkylammonium tetrafluoroborates}

Following is a typical preparative procedure for alkylammonium tetrafluoroborates. Alkyl or phenyl ammonium tetrafluoroborates were prepared according to the literature procedures of Kukhar. ${ }^{26}$ They were prepared by reaction of the corresponding alkylammonium chlorides with triethyloxonium tetrafluoroborate in acetonitrile. Since most of the salts are hygroscopic, they are collected under nitrogen, sealed and sent for microanalysis.

2.2.1. Octylammonium tetrafluoroborate (2). To a solution of 1-octylamine $(10 \mathrm{~mL}, 56.9 \mathrm{mmol})$ in $\mathrm{CH}_{2} \mathrm{Cl}_{2}$ $(20 \mathrm{~mL})$ in an ice bath were slowly added concentrated hydrochloric acid $(4.75 \mathrm{~mL}, 56.9 \mathrm{mmol})$. The mixture was 
stirred for another $5 \mathrm{~h}$. White suspension was collected by filtration and further purified by recrystallization from $\mathrm{CH}_{2} \mathrm{Cl}_{2}$. The crystals were collected under nitrogen and dried in vacuum to give colorless octylammonium chloride (6.69 g, 71\%): ${ }^{1} \mathrm{H}$ NMR (400 MHz, DMSO-d 6 ) $\delta 8.08$ (s, $3 \mathrm{H}), 2.70(\mathrm{t}, J=7.6 \mathrm{~Hz}, 2 \mathrm{H}), 1.55-1.50(\mathrm{~m}, 2 \mathrm{H}), 1.35-1.20$ $(\mathrm{m}, 10 \mathrm{H}), 0.84(\mathrm{t}, J=6.8 \mathrm{~Hz}, 3 \mathrm{H}) ;{ }^{13} \mathrm{C}$ NMR $(100 \mathrm{MHz}$, DMSO-d $\left._{6}\right) \delta 38.7,31.2,28.5,26.9,25.9,22.1,14.0$; IR $(\mathrm{KBr}) \nu 3400-2700 \mathrm{~cm}^{-1}\left(\mathrm{NH}_{3}^{+}\right.$, br, s). To a solution of octylammonium chloride $(3 \mathrm{~g}, 18 \mathrm{mmol})$ in dried acetonitrile $(18 \mathrm{~mL})$ under nitrogen at room temperature was added triethyloxonium tetrafluoroborate $\left(\mathrm{Et}_{3} \mathrm{O}^{+} \mathrm{BF}_{4}^{-}\right.$, $18 \mathrm{mmol}$ ). The solution was refluxed for $24 \mathrm{~h}$ until outgassing of alkyl chloride was no longer observed. In some occasion, the completion of reaction was traced by ${ }^{1} \mathrm{H}$ NMR. The solid obtained after evaporation of the solvent was further purified by recrystallization from ethyl acetate. The product was collected by filtration under nitrogen, and dried in vacuum to give colorless crystals. $(2.76 \mathrm{~g}, 71 \%):{ }^{1} \mathrm{H}$ NMR (400 MHz, DMSO-d $\left.{ }_{6}\right) \delta 7.60(\mathrm{~s}, 3 \mathrm{H}), 2.75(\mathrm{t}, J=$ $7.6 \mathrm{~Hz}, 2 \mathrm{H}), 1.52-1.46(\mathrm{~m}, 2 \mathrm{H}), 1.35-1.20$ (m, 10H), 0.85 $(\mathrm{t}, J=6.8 \mathrm{~Hz}, 3 \mathrm{H}) ;{ }^{13} \mathrm{C} \mathrm{NMR}\left(100 \mathrm{MHz}, \mathrm{CD}_{3} \mathrm{CN}\right) \delta 41.4$, $32.5,29.8,29.7,27.7,26.9,23.4$, 14.4; IR (KBr) $\nu$ 3400$3200 \mathrm{~cm}^{-1}\left(\mathrm{NH}_{3}^{+}\right.$, br), $1200-1000 \mathrm{~cm}^{-1}$ (B-F, br). Anal. calcd for $\mathrm{C}_{8} \mathrm{H}_{20} \mathrm{BF}_{4} \mathrm{~N}$ : C, 44.27; H, 9.29; N, 6.45. Found: C, 44.79; H, 9.42; N, 6.50 .

2.2.2. 1,6-Hexanediammonium bistetrafluoroborate (3). 1,6-Hexanediammonium dichloride obtained was purified by washing with methanol and $\mathrm{CH}_{2} \mathrm{Cl}_{2}$ to give colorless solid (75\%): ${ }^{1} \mathrm{H}$ NMR (400 MHz, DMSO-d 6 ) $\delta 8.10(\mathrm{~s}, 6 \mathrm{H})$, $2.73(\mathrm{t}, J=7.6 \mathrm{~Hz}, 4 \mathrm{H}), 1.57-1.53(\mathrm{~m}, 4 \mathrm{H}), 1.31-1.28(\mathrm{~m}$, $4 \mathrm{H}) ;{ }^{13} \mathrm{C}$ NMR (100 MHz, DMSO-d 6 ) $\delta 39.2,27.4,26.0$; IR $(\mathrm{KBr}) \nu 3400-2700 \mathrm{~cm}^{-1}\left(\mathrm{NH}_{3}^{+}\right.$, br). 1,6-Hexanediammonium bistetrafluoroborate obtained was recrystallized from acetonitrile to give colorless solid. (46\%): ${ }^{1} \mathrm{H}$ NMR $\left(400 \mathrm{MHz}, \mathrm{CD}_{3} \mathrm{CN}\right) \delta 5.82(\mathrm{~s}, 6 \mathrm{H}), 2.95(\mathrm{t}, J=7.6 \mathrm{~Hz}$, $4 \mathrm{H}), 1.66-1.59(\mathrm{~m}, 4 \mathrm{H}), 1.41-1.31(\mathrm{~m}, 4 \mathrm{H}) ;{ }^{13} \mathrm{C} \mathrm{NMR}$ (100 MHz, CD 3 CN) $\delta 41.2,27.3,26.1$; IR (KBr) $\nu$ 3300_ $3200 \mathrm{~cm}^{-1}\left(\mathrm{NH}_{3}^{+}\right.$, br), $1200-1000 \mathrm{~cm}^{-1}$ (B-F, br). Anal. calcd for $\mathrm{C}_{6} \mathrm{H}_{18} \mathrm{~B}_{2} \mathrm{~F}_{8} \mathrm{~N}_{2}$ : C, 24.69; H, 6.22; N, 9.60. Found: C, 25.02; H, 6.22; N, 9.43.

2.2.3. Hexadecylammonium tetrafluoroborate (4). Hexadecyl-ammonium chloride obtained was recrystallized from $\mathrm{CHCl}_{3}$ to give colorless solid $(79 \%)$ : ${ }^{1} \mathrm{H}$ NMR $\left(400 \mathrm{MHz}, \mathrm{DMSO}_{6}\right) \delta 7.88(\mathrm{~s}, 3 \mathrm{H}), 2.72(\mathrm{t}, J=7.6 \mathrm{~Hz}$, $2 \mathrm{H}), 1.53-1.48(\mathrm{~m}, 2 \mathrm{H}), 1.35-1.15(\mathrm{~m}, 26 \mathrm{H}), 0.84(\mathrm{t}, J=$ $6.8 \mathrm{~Hz}, 3 \mathrm{H}) ;{ }^{13} \mathrm{C}$ NMR $\left(100 \mathrm{MHz}, \mathrm{DMSO}-\mathrm{d}_{6}\right) \delta 38.7,31.4$, $29.1,29.1,29.0,28.9,28.8,28.6,27.0,25.9,22.2$, 14.1; IR $(\mathrm{KBr}) \nu 3200-2700 \mathrm{~cm}^{-1}\left(\mathrm{NH}_{3}^{+}, \mathrm{br}\right)$. Hexadecyl ammonium tetrafluoroborate was recrystallized from THF to give colorless solid (53\%): ${ }^{1} \mathrm{H}$ NMR (400 MHz, DMSO$\left.\mathrm{d}_{6}\right) \delta 7.56(\mathrm{~s}, 3 \mathrm{H}), 2.7(\mathrm{t}, J=7.6 \mathrm{~Hz}, 2 \mathrm{H}), 1.51-1.45(\mathrm{~m}, 2 \mathrm{H})$, $1.36-1.18(\mathrm{~m}, 26 \mathrm{H}), 0.84(\mathrm{t}, J=6.8 \mathrm{~Hz}, 3 \mathrm{H}) ;{ }^{13} \mathrm{C} \mathrm{NMR}$ $\left(100 \mathrm{MHz}, \mathrm{DMSO}-\mathrm{d}_{6}\right) \delta 38.9,31.3,29.1,29.0,28.9,28.8$, 28.6, 27.1, 25.8, 22.2, 14.1; IR (KBr) $\nu 3300-3100 \mathrm{~cm}^{-1}$ $\left(\mathrm{NH}_{3}^{+}, \mathrm{br}\right), 1200-1000 \mathrm{~cm}^{-1}$ (B-F, br). Anal. calcd for $\mathrm{C}_{16} \mathrm{H}_{36} \mathrm{BF}_{4} \mathrm{~N}$ : C, 58.36; H, 11.02; N, 4.25. Found: C, 58.68; $\mathrm{H}, 11.00 ; \mathrm{N}, 4.26$.

2.2.4. tert-Butylammonium tetrafluoroborate (5). tertButylammonium chloride was crystallized from ethanol to give colorless solid. (69\%): ${ }^{1} \mathrm{H}$ NMR (400 MHz, DMSO-d ${ }_{6}$ ) $\delta 8.21(\mathrm{~s}, 3 \mathrm{H}), 1.28(\mathrm{~s}, 9 \mathrm{H}) ;{ }^{13} \mathrm{C}$ NMR $(100 \mathrm{MHz}$, DMSO$\left.\mathrm{d}_{6}\right) \delta 51.2,27.4$; IR (KBr) $\nu 3200-2900 \mathrm{~cm}^{-1}\left(\mathrm{NH}_{3}^{+}, \mathrm{br}, \mathrm{m}\right)$. tert-Butylammonium tetrafluoroborate was recrystallized from acetonitrile to give colorless solid (39\%): ${ }^{1} \mathrm{H}$ NMR $\left(400 \mathrm{MHz}, \mathrm{DMSO}_{-} \mathrm{d}_{6}\right) \delta 7.74(\mathrm{~s}, 3 \mathrm{H}), 1.23(\mathrm{~s}, 9 \mathrm{H}) ;{ }^{13} \mathrm{C}$ NMR (100 MHz, DMSO-d $\left.{ }_{6}\right) \delta 51.7,27.7$; IR (KBr) $\nu 3300$ $3100 \mathrm{~cm}^{-1}\left(\mathrm{NH}_{3}^{+}\right.$, br), 1300-1000 cm ${ }^{-1}$ (B-F, br). Anal. calcd for $\mathrm{C}_{4} \mathrm{H}_{12} \mathrm{BF}_{4} \mathrm{~N}$ : C, 29.85; H, 7.51; N, 8.70. Found: C, $29.79 ; \mathrm{H}, 7.65 ; \mathrm{N}, 8.43$.

2.2.5. Benzylammonium tetrafluoroborate (6). Benzylammonium chloride obtained was crystallized from $\mathrm{MeOH}$ to give colorless solid (87\%): ${ }^{1} \mathrm{H}$ NMR (400 MHz, DMSO$\left.\mathrm{d}_{6}\right) \delta 8.46(\mathrm{~s}, 3 \mathrm{H}), 7.50-7.36(\mathrm{~m}, 5 \mathrm{H}), 3.99(\mathrm{~s}, 2 \mathrm{H}) ;{ }^{13} \mathrm{C}$ NMR (100 MHz, DMSO-d 6 ) $\delta$ 134.1, 128.9, 128.5, 128.4, 42.1 ; IR (KBr) $\nu 3200-2700 \mathrm{~cm}^{-1}\left(\mathrm{NH}_{3}^{+}\right.$, br $), 1600 \mathrm{~cm}^{-1}$ $(\mathrm{C}=\mathrm{C})$. Benzylammonium tetrafluoroborate obtained was crystallized from acetonitrile to give colorless solid $(75 \%)$ : ${ }^{1} \mathrm{H}$ NMR (400 MHz, CD $\left.{ }_{3} \mathrm{CN}\right) \delta$ 7.48-7.43 (m, 5H), 6.46 (s, $3 \mathrm{H}), 4.15$ (s, 2H); ${ }^{13} \mathrm{C}$ NMR $\left(100 \mathrm{MHz}, \mathrm{CD}_{3} \mathrm{CN}\right) \delta 133.1$, 130.4, 130.4, 130.1, 44.9; IR (KBr) $\nu 3300-3100 \mathrm{~cm}^{-1}$ $\left(\mathrm{NH}_{3}^{+}\right.$, br $), 1615 \mathrm{~cm}^{-1}(\mathrm{C}=\mathrm{C}), 1200-1000 \mathrm{~cm}^{-1}(\mathrm{~B}-\mathrm{F})$. Anal. calcd for $\mathrm{C}_{7} \mathrm{H}_{10} \mathrm{BF}_{4} \mathrm{~N}$ : C, 43.12; H, 5.17; N, 7.18. Found: C, 43.44; H, 5.15; N, 7.24.

2.2.6. Diethylammonium tetrafluoroborate (7). Diethylammonium chloride obtained was recrystallized from acetonitrile and followed by washing with hexane and ether to give colorless solid $(68 \%)$ : ${ }^{1} \mathrm{H}$ NMR $(400 \mathrm{MHz}$, DMSO-d $\left.{ }_{6}\right) \delta 9.01(\mathrm{~s}, 2 \mathrm{H}), 2.90-2.81(\mathrm{~m}, 4 \mathrm{H}), 1.17(\mathrm{t}, J=$ $7.6 \mathrm{~Hz}, 6 \mathrm{H}) ;{ }^{13} \mathrm{C}$ NMR $\left(100 \mathrm{MHz}, \mathrm{DMSO}_{-} \mathrm{d}_{6}\right) \delta 41.2,10.9$; IR $(\mathrm{KBr}) \nu 3300-2700 \mathrm{~cm}^{-1}\left(\mathrm{NH}_{2}^{+}\right.$, br). Diethylammonium tetrafluoroborate obtained was recrystallized from ethyl acetate to give colorless solid (44\%): ${ }^{1} \mathrm{H}$ NMR $(400 \mathrm{MHz}$, DMSO-d $\left._{6}\right) \delta 8.20(\mathrm{~s}, 2 \mathrm{H}), 3.02(\mathrm{q}, J=7.2 \mathrm{~Hz}, 4 \mathrm{H}), 1.15(\mathrm{t}$, $J=7.6 \mathrm{~Hz}, 6 \mathrm{H}) ;{ }^{13} \mathrm{C}$ NMR $\left(100 \mathrm{MHz}, \mathrm{DMSO}-\mathrm{d}_{6}\right) \delta 42.0$, 11.7; IR (KBr) $\nu$ 3200-2900 cm $\mathrm{cm}^{-1}\left(\mathrm{NH}_{2}^{+}\right.$, br), 1300 $900 \mathrm{~cm}^{-1}$ (B-F, br). Anal. calcd for $\mathrm{C}_{4} \mathrm{H}_{12} \mathrm{BF}_{4} \mathrm{~N}$ : C, 29.85; H, 7.51; N, 8.70. Found: C, 29.83; H, 7.67; N, 8.58.

2.2.7. Triethylammonium tetrafluoroborate $(8) .^{27}$ Triethylammonium chloride prepared was recrystallized from acetonitrile to give colorless solid (48\%): ${ }^{1} \mathrm{H}$ NMR (400 MHz, DMSO-d $\left.{ }_{6}\right) \delta 10.60(\mathrm{~s}, 1 \mathrm{H}), 3.06-3.00(\mathrm{~m}, 6 \mathrm{H})$, $1.19(\mathrm{t}, J=7.6 \mathrm{~Hz}, 9 \mathrm{H}) ;{ }^{13} \mathrm{C}$ NMR $\left(100 \mathrm{MHz}, \mathrm{DMSO}_{-} \mathrm{d}_{6}\right) \delta$ 45.2, 8.4; IR (KBr) $\nu$ 3200-2900 cm $\mathrm{cm}^{-1}\left(\mathrm{NH}^{+}\right.$, br). Triethylammonium tetrafluoroborate obtained was precipitated from ethyl acetate to give colorless solid $(38 \%):{ }^{1} \mathrm{H}$ NMR (400 MHz, DMSO-d 6 ) $\delta 9.01$ (s, 1H), 3.08 (q, $J=$ $7.2 \mathrm{~Hz}, 6 \mathrm{H}), 1.16(\mathrm{t}, J=7.6 \mathrm{~Hz}, 9 \mathrm{H}) ;{ }^{13} \mathrm{C} \mathrm{NMR}(100 \mathrm{MHz}$, DMSO-d 6 ) $\delta 46.0,8.9$; IR (KBr) $\nu 3200-2900 \mathrm{~cm}^{-1}\left(\mathrm{NH}^{+}\right.$, br), $1300-900 \mathrm{~cm}^{-1}$ (B-F, br). Anal. calcd for $\mathrm{C}_{6} \mathrm{H}_{16} \mathrm{BF}_{4} \mathrm{~N}$ : C, 38.13; H, 8.53; N, 7.41. Found: C, 38.30; H, 8.73; N, 7.37 .

2.2.8. (1,1-Diphenylmethyl)ammonium tetrafluoroborate (9). (1,1-Diphenylmethyl)ammonium chloride obtained was recrystallized from ethanol to give colorless solid (91\%): ${ }^{1} \mathrm{H}$ NMR (400 MHz, DMSO-d 6 ) $\delta 9.25$ (s, $3 \mathrm{H}), 7.56(\mathrm{~d}, J=7.2 \mathrm{~Hz}, 4 \mathrm{H}), 7.40(\mathrm{t}, J=7.6 \mathrm{~Hz} 4 \mathrm{H}), 7.33(\mathrm{t}$, $J=7.6 \mathrm{~Hz}, 2 \mathrm{H}), 5.61(\mathrm{~s}, 1 \mathrm{H}) ;{ }^{13} \mathrm{C}$ NMR $(100 \mathrm{MHz}$, DMSO-d $\left.{ }_{6}\right) \delta 138.8,129.2,128.7,127.8,57.6$; IR $(\mathrm{KBr}) \nu$ 
$3300-2600 \mathrm{~cm}^{-1}\left(\mathrm{NH}_{3}^{+}\right.$, br), $1610 \mathrm{~cm}^{-1}$ (C=C, s). (1,1Diphenylmethyl)ammonium tetrafluoroborate obtained was recrystallized from $\mathrm{CH}_{2} \mathrm{Cl}_{2}$ to give colorless solid (57\%): ${ }^{1} \mathrm{H}$ NMR (400 MHz, CD $\mathrm{CN}_{3}$ ) $7.49-7.26(\mathrm{~m}, 10 \mathrm{H}), 7.26(\mathrm{~s}$, $3 \mathrm{H}), 5.69(\mathrm{~s}, 1 \mathrm{H}),{ }^{13} \mathrm{C} \mathrm{NMR}\left(100 \mathrm{MHz}, \mathrm{CD}_{3} \mathrm{CN}\right) \delta 137.2$, $130.3,130.3,128.4,60.0$; IR $(\mathrm{KBr}) \nu 3300-3100 \mathrm{~cm}^{-1}$ $\left(\mathrm{NH}_{3}^{+}\right.$, br), $1597 \mathrm{~cm}^{-1}(\mathrm{C}=\mathrm{C}), 1200-900 \mathrm{~cm}^{-1}$ (B-F, br). Elemental analysis suggested that the salt is a monohydrate. Anal. calcd for $\mathrm{C}_{13} \mathrm{H}_{14} \mathrm{BF}_{4} \mathrm{~N} \cdot\left(\mathrm{H}_{2} \mathrm{O}\right)$ : $\mathrm{C}, 54.01 ; \mathrm{H}$, 5.58; N, 4.85. Found: C, 54.87; H, 5.38; N, 4.92.

2.2.9. L-Phenylalanine methyl ester ammonium tetrafluoroborate (10). To a solution of L-phenylalanine $(5.0 \mathrm{~g}$, $29.8 \mathrm{mmol})$ in distilled $\mathrm{MeOH}(50 \mathrm{~mL})$ under nitrogen at at $0{ }^{\circ} \mathrm{C}$ was added distilled thionyl chloride $(3.28 \mathrm{~mL}$, $44.7 \mathrm{mmol}$ ) dropwise. After addtion, the mixture was stirred at room temperature for $24 \mathrm{~h}$. The reaction was followed by TLC, using BAW (butanol-acetic acid- $\mathrm{H}_{2} \mathrm{O}=4: 1: 1$ ) as the mobile phase. After completion of the reaction, methanol was removed by distillation. Ether $(400 \mathrm{~mL})$ was added to precipitate the product. The solid product was collected by suction filtration under nitrogen, followed by washing with iced ether, and dried under vacuum to give L-phenylalanine methyl ester ammonium chloride $(5.91 \mathrm{~g}, 91 \%)$ : ${ }^{1} \mathrm{H}$ NMR (400 MHz, DMSO-d $\left.{ }_{6}\right) \delta 8.53(\mathrm{~s}, 3 \mathrm{H}), 7.35-7.23(\mathrm{~m}, 3 \mathrm{H})$, $7.22(\mathrm{~d}, J=6.8 \mathrm{~Hz}, 2 \mathrm{H}), 4.28(\mathrm{t}, J=6.8 \mathrm{~Hz}, 1 \mathrm{H}), 3.66(\mathrm{~s}$, $3 \mathrm{H}), 3.14(\mathrm{dd}, J=14.0,6.0 \mathrm{~Hz}, 1 \mathrm{H}) ; 3.06(\mathrm{dd}, J=13.8$, $7.0 \mathrm{~Hz}, 1 \mathrm{H}) ;{ }^{13} \mathrm{C}$ NMR $\left(100 \mathrm{MHz}, \mathrm{DMSO}-\mathrm{d}_{6}\right) \delta 169.1$, $134.4,129.2,128.4,127.1,53.2,52.5,35.9$; IR $(\mathrm{KBr}) \nu$ $3300-2700 \mathrm{~cm}^{-1}\left(\mathrm{NH}_{3}^{+}\right.$, br $), \quad 1766 \mathrm{~cm}^{-1} \quad(\mathrm{C}=\mathrm{O})$. $1600 \mathrm{~cm}^{-1} \quad(\mathrm{C}=\mathrm{C})$. L-phenylalanine methyl ester ammonium tetrafluoroborate obtained was precipitated from $\mathrm{CH}_{2} \mathrm{Cl}_{2}$ to give colorless solid. (18\%): ${ }^{1} \mathrm{H} \mathrm{NMR}$ $\left(400 \mathrm{MHz}, \mathrm{DMSO}_{-} \mathrm{d}_{6}\right) \delta 8.33(\mathrm{~s}, 3 \mathrm{H}), 7.37-7.22(\mathrm{~m}, 3 \mathrm{H})$, $7.21(\mathrm{~d}, J=6.8 \mathrm{~Hz}, 2 \mathrm{H}), 4.32(\mathrm{t}, J=6.8 \mathrm{~Hz}, 1 \mathrm{H}), 3.68(\mathrm{~s}$, 3H), 3.12-3.02 (m, 2H); ${ }^{13} \mathrm{C}$ NMR (100 MHz, DMSO-d $\left.\mathrm{d}_{6}\right)$ $169.5,134.5,129.4,128.7,127.4,53.2,52.7,36.0$; IR (KBr) $\nu$ 3300-2800 cm $\mathrm{cm}^{-1}\left(\mathrm{NH}_{3}^{+}\right.$, br $), 1747 \mathrm{~cm}^{-1} \quad(\mathrm{C}=\mathrm{O})$, $1609 \mathrm{~cm}^{-1} \quad(\mathrm{C}=\mathrm{C}), 1200-900 \mathrm{~cm}^{-1}$ (B-F, br). Anal. calcd for $\mathrm{C}_{10} \mathrm{H}_{14} \mathrm{BF}_{4} \mathrm{NO}_{2}$ : C, 44.98; H, 5.28; N, 5.25. Found: C, 44.78; H, 5.25; N, 5.32.

\section{Acknowledgements}

We thank the National Science Council of Republic of China for the financial support. (NSC 92-2113-M-002-020).

\section{References and notes}

1. Burger, C.; Kreuzer, F.-H. Silicon in Polymer Synthesis; Kricheldorf, H. R., Ed.; Springer: Berlin, 1996; pp 113-222.

2. (a) Brook, M. A. Silicon in Organic, Organometallic, and Polymer Chemistry; Wiley: New York, 2000. (b) Clarson, S. J.; Semlyen, J. A. Siloxane Polymers; Prentice Hall: New Jersey, 1993.

3. (a) Kendrick, T. C.; Parbhoo, B.; White, J. W. The Chemistry of Organic Silicon Compounds; Patai, S., Rappoport, Z., Eds.; Wiley: New York, 1989; Vol. 2, pp 1289-1308. (b) Voronkov, M. G.; Mileshkevich, V. P.; Yuzhelevskii, Yu. A. The Siloxane
Bond; Plenum: New York, 1978; pp 203-212. (c) Kendrick, T. C.; Parbhoo, B. M.; White, J. W. Comprehensive Polymer Science; Allen, G., Bevington, J. C., Eastmond, G. C., Ledwith, A., Russo, S., Sigwalt, P., Eds.; Pergamon: Oxford, 1989; Vol. 4, pp 459-492. (d) Mazurek, M. Recent Advances in Anionic Polymerization; Hogen-Esch, T. E., Smid, J., Eds.; Elsevier: New York, 1987; pp 329-349.

4. (a) Laita, Z.; Jelínek, M. J. Polym. Sci. 1966, B4, 739-745. (b) Mazurek, M.; Chojnowski, J. Makromol. Chem. 1977, 178, 1005-1017. (c) Ricard, A. Eur. Polym. J. 1979, 15, 1-4. (d) Grubb, W. T.; Osthoff, R. C. J. Am. Chem. Soc. 1955, 77, 1405-1411. (e) Hurd, D. T.; Osthoff, R. C.; Corrin, M. L. J. Am. Chem. Soc. 1954, 76, 249-252.

5. Olliff, C. J.; Pickering, G. R.; Rutt, K. J. J. Inorg. Nucl. Chem. 1980, 42, 1201-1202.

6. (a) Leung, M.; Mandal, A. B.; Wang, C.-C.; Lee, G.-H.; Peng, S.-M.; Cheng, H.-L.; Her, G.-R.; Chao, I.; Lu, H.-F.; Sun, Y.-C.; Shiao, M.-Y.; Chou, P.-T. J. Am. Chem. Soc 2002, 124, 4287-4297. (b) Chen, J.-A.; Lai, J.-L.; Lee, G. H.; Wang, Y.; $\mathrm{Su}$, J. K.; Yeh, H.-C.; Lin, W.-Y.; Leung, M.-k. Org. Lett. 2001, 3, 3999-4002. (c) Liao, C.-F.; Lai, J.-L.; Chen, J.-A.; Chen, H.-T.; Cheng, H.-L.; Her, G.-R.; Su, J. K.; Wang, Y.; Lee, G. H.; Leung, M.; Wang, C.-C. J. Org. Chem. 2001, 66, 2566-2571.

7. Spielvogel, D. E.; Frye, C. L. J. Organomet. Chem. 1978, 161, 165-169.

8. Tsyganov, Yu. V.; Mileshkevich, V. P. Zh. Obshch. Khim. 1982, 52, 1849-1854. CA 97: 163084.

9. Lewis, R. N. J. Am. Chem. Soc. 1948, 70, 1115-1117.

10. Shklover, V. E.; Bokii, N. G.; Struchkov, Yu. T.; Andrianov, K. A.; Zavin, B. G.; Svistunov, V. S. Zh. Strukt. Khim. 1974, 15, 841-849. CA 81:178259 b.

11. Voronkov, M. G.; Mileshkevich, V. P.; Yuzhelevskii, Yu. A. The Siloxane Bond; Plenum: New York, 1978, p 12.

12. The values of $E_{\mathrm{s}}$ are $82 \mathrm{~kJ} / \mathrm{mol}(19.6 \mathrm{kcal} / \mathrm{mol})$ for the cisisomer and $73 \mathrm{~kJ} / \mathrm{mol}(17.5 \mathrm{kcal} / \mathrm{mol})$ for the trans isomer. For reference, see: Voronkov, M. G.; Klyuchnikov, V. A.; Mironenko, E. V.; Shvets, G. N.; Danilova, T. F.; Khudobin, Yu. I. J. Organomet. Chem. 1991, 406, 91-97.

13. Dias, F. B.; Lima, J. C.; Maçanita, A. L.; Horta, A.; Piérola, I. F. J. Phys. Chem. A 2000, 104, 17-24.

14. Jeffers, P. M. J. Phys. Chem. 1972, 76, 2829-2832.

15. For discussion of negative enthalpy, see (a) Houk, K. N.; Rondan, N. G. J. Am. Chem. Soc. 1984, 106, 4293-4294. (b) Gorman, A. A.; Lovering, G.; Rodgers, M. A. J. J. Am. Chem. Soc. 1979, 101, 3050-3055, and references cited therein.

16. (a) Tsyganov, Yu. V.; Mileshkevich, V. P. J. Gen. Chem. USSR. (Engl. Transl.) 1980, 1465-1468. (b) Wilczek, L.; Chojnowski, J. Macromolecules 1981, 14, 9-17.

17. Le Questel, J.-Y.; Berthelot, M.; Laurence, C. J. Phys. Org. Chem. 2000, 13, 347-358.

18. The hydrogen bond acceptor basicities $\beta$ of DMSO and acetonitrile are 0.76 and 0.31 respectively, which indicates that DMSO and acetonitrile both are hydrogen bond acceptors. For reference, see Kamlet, M. J.; Abboud, J. L. M.; Taft, R. W. Prog. Phys. Org. Chem. 1981, 13, 485-630.

19. Farooq, O.; Tiers, G. V. D. J. Org. Chem. 1994, 59, 2122-2124 and references cited therein in the introduction of the article.

20. It has been reported that tetraalkylammonium salts would associate in organic solvents. For references, see. (a) Das, B.; Saha, N.; Hazra, D. K. J. Chem. Eng. Data 2000, 45, 353-357. (b) Islam, N.; Zaidi, S. B. A.; Ansari, A. A. Bull. Chem. Soc. Jpn 
1989, 62, 309-316. (c) Muhuri, P. K.; Hazra, D. K. J. Chem. Soc., Faraday Trans. 1991, 87, 3511-3513. (d) Jones, R. A. Quaternary Ammonium Salts; Academic: London, 2001, pp 815. For the data of enthalpies of transfer from a standard solvent to DMSO, see Marcus, Y. Ion Properties; Marcel Dekker: New York, 1997, pp 228-229.

21. (a) Miyabe, K.; Taguchi, S.; Kasahara, I.; Goto, K. J. Phys. Chem. B 2000, 104, 8481-8490. (b) Szwarc, M. Acc. Chem. Res. 1969, 87-96.

22. (a) Farooq, O. J. Organomet. Chem. 2000, 613, 239-243.

(b) Farooq, O. J. Chem. Soc., Perkin Trans. 1 1998, 661-665.

23. Tartakovskaya, L. M.; Kopylov, V. M.; Zhdanov, A. A. Vysokomol. Soedin., Ser. B 1984, 26(3), 234-238. CA 101:73186.

24. (a) Marks, T. J.; Seyam, A. M. Inorg. Chem. 1974, 13,
1624-1627. (b) Bulkowski, J. E.; Stacy, R.; van Dyke, C. H. J. Organomet. Chem. 1975, 87, 137-143. (c) Clark, H. C.; O'Brien, R. J. Inorg. Chem. 1963, 2, 1020-1022. (d) Booth, M. R.; Cardin, D. J.; Carey, N. A. D.; Clark, H. C.; Sreenathan, B. R. J. Organomet. Chem. 1970, 21, 171-180.

25. (a) Johnson, S. E.; Payne, J. S.; Day, R. O.; Holmes, J. M.; Holmes, R. R. Inorg. Chem. 1989, 28, 3190-3198. (b) Ugi, I.; Marquarding, D.; Klusacek, H.; Gillespie, P.; Ramirez, F. Acc. Chem. Res. 1971, 4, 288-296.

26. Kukhar, V. P.; Pasternak, V. I.; Shevchenko, I. V.; Shevchenko, M. V.; Marchenko, A. P.; Makovetskii, Yu. P. J. Org. Chem. USSR (Engl. Transl.). 1981, 161-166.

27. Mohamed, K. S.; Padma, D. K. Indian J. Chem. 1988, 27A, 759-763. CA 110: 106911. 